\title{
Estimasi Biaya dan Evaluasi Program Intervensi Pemberian Pangan Olahan untuk Keperluan Medis Khusus (PKMK) untuk Perbaikan Status Gizi di Banyumas, Jawa Tengah
}

\author{
Cost Estimation and Intervention Program Evaluation of Food for Specific \\ Medical Purposes (FSMP) for Nutrition Status Improvement of Children Under 5 \\ at Banyumas District, Central Java
}

\author{
Hanifah Hasnur', Febyolla Presilawati² \\ ${ }^{1}$ Fakultas Kesehatan Masyarakat, Universitas Muhammadiyah Aceh \\ ${ }^{1}$ Fakultas Ekonomi, Universitas Muhammadiyah Aceh
}

Korespondensi: Hanifah Hasnur

E-mail: hanifahhasnur@gmail.com

\begin{abstract}
Abstrak
Pemerintah Banyumas telah melaksanakan suatu intervensi Pemberian Pangan Olahan untuk Keperluan Medis Khusus (PKMK) dengan suplementasi nutrisi $1.5 \mathrm{kcal} / \mathrm{mL}$ pada tahun 2019. Namun, belum pernah dilakukan evaluasi baik dari segi luaran maupun biaya intervensi. Sehingga, penelitian ini diperlukan guna memberikan gambaran awal mengenai sumber daya yang dibutuhkan untuk perumusan perencanaan intervensi pada masa yang akan datang. Penelitian ini bertujuan untuk mengetahui estimasi biaya yang dibutuhkan untuk intervensi PKMK dan mengetahui luaran dari intervensi. Evaluasi ekonomi dilakukan secara parsial dengan menghitung biaya dari perspektif institusi pelaksana program dan hasil luaran dari intervensi berupa peningkatan BB dan TB. Sampel penelitian sebanyak 40 balita yang telah dipilih berdasarkan skrining gizi balita yang tidak mampu mengkonsumsi makanan yang ada dan memiliki asupan nutrisi yang inadekuat. Hasil studi menunjukkan total biaya intervensi sebesar Rp.219.817.000 untuk 40 anak (Rp.5.495.438 per anak) di mana untuk suplementasi nutrisi $1.5 \mathrm{kcal} / \mathrm{mL}$ per anak sebesar Rp.1.395.850. Terjadi peningkatan rata-rata berat dan tinggi anak sebesar 0.64-kilogram dan 0.47-centimeter dalam 28 hari setelah program selesai. Estimasi biaya dari hasil studi ini dapat lebih rendah pada intervensi selanjutnya apabila peralatan yang ada digunakan kembali. Studi ini dapat dijadikan referensi untuk pelaksanaan intervensi PKMK dengan lingkup cakupan / kriteria subjek yang sama atau dalam skala yang lebih luas.

Kata kunci: MT, perawatan balita stunting, balita gizi buruk, program intervensi PKMK
\end{abstract}

\begin{abstract}
The Government of Banyumas has implemented an intervention in the Provision of Processed Food for Special Medical Purposes (FSMP) with nutritional supplementation of $1.5 \mathrm{kcal} / \mathrm{mL}$ in 2019. However, there is no evaluation has been carried out, both of outcome and the cost of the intervention. So that, it is necessary to provide an initial picture of the resources needed for the formulation of future intervention plans. This study aims to determine the estimated cost required for FSMP intervention and to determine the outcome of the intervention. The economic evaluation was carried out partially by calculating costs from the perspective of the program implementing institution and the outcome of the intervention in the form of increasing weight and height. The research sample was 40 toddlers who had been selected based on nutritional screening of toddlers who were unable to consume existing foods and had inadequate nutritional intake. The results of the study showed that the total intervention cost was Rp.219.817.000 for 40 children (Rp.5.495.438 per child) where for nutritional supplementation of $1.5 \mathrm{kcal} / \mathrm{mL}$ per child was Rp.1.395.850. There was an increase in the average weight and height of children by 0.64-kilogram and 0.47-centimeter in 28 days after the program was completed. The estimated cost from the results of this study could be lower in subsequent interventions if the equipment is reused. This study can be used as a reference for FSMP interventions with the same subject coverage/criteria or on a wider scale.

Key words: Food supplementary, stunting care for children under five, malnourished children, FSMP intervention program
\end{abstract}




\section{Pendahuluan}

Kemunduran di bidang kesehatan dapat berdampak terhadap hampir seluruh lini kehidupan manusia. Begitu pula dengan permasalahan kesehatan terkait gizi yang dampaknya juga besar. Anak yang mengalami stunting pada masa balitanya, dapat mengalami kemunduran dalam hal kecerdasan kognitif maupun perkembangan fisiknya. Pada masa dewasa, balita yang mengalami stunting, berpotensi mengalami kemunduran dalam hal produktivitas kerja. Hal ini dapat berdampak terhadap terganggunya perekonomian keluarga, masyarakat bahkan negara (Wong B, et al, 2017).

Fakta menunjukkan bahwa 3 dari 10 anak balita di Indonesia mengalami stunting (Unicef, 2020). Angka stunting pada anak balita di Indonesia mencapai $30.8 \%$ dari total balita yang ada pada tahun 2018 (RKD, 2018). Angka ini turun menjadi 26.7\% pada tahun 2019 (Kemenkes RI, 2019).

Jumlah balita stunting di Indonesia masih sangat tinggi dibandingkan dengan negara tetangga seperti Malaysia (21.8\%) dan Singapura (4.4\%). Hal ini telah menjadikan stunting sebagai masalah kesehatan prioritas yang dimasukkan ke dalam RPJMN 2020-2024. Pemerintah Indonesia menargetkan prevalensi stunting pada anak balita turun menjadi $14 \%$ pada tahun 2024. Ini merupakan tantangan yang perlu ditindaklanjuti dengan program-program strategis agar target nasional ini bisa tercapai pada tahun 2024.

Sementara itu, dalam Peraturan Menteri Kesehatan (Permenkes) nomor 14 tahun 2019 disebutkan bahwa Pemerintah Daerah wajib menerapkan Standar Pelayanan Minimal (SPM) untuk perbaikan gizi balita. Ini artinya Pemerintah Daerah adalah pelaksana kunci dalam melaksanakan intervensi guna menurunkan jumlah balita stunting di daerahnya.

Pemberian Makanan Olahan untuk Keperluan
Medis Khusus (PKMK) adalah salah satu intervensi yang terbukti efektif memperbaiki status gizi balita. Hal ini dapat dilihat dari hasil studi yang pernah dilaksanakan oleh Deavara et al (2018) dengan melakukan uji Randomized Control Trial (RCT) terhadap anak balita dengan permasalahan gizi tidak adekuat yang direkrut dari 3 desa di Jakarta Pusat (Manggarai, Kenari, dan Paseban). Jenis pangan olahan yang digunakan pada intervensi ini adalah produk liquid $1.5 \mathrm{kcal} / \mathrm{mL}$ dan $1.0 \mathrm{kcal} / \mathrm{mL}$, yaitu susu cair suplementasi nutrisi anak yang diformulasikan khusus (Nutrinidrink multi FibeR). Hasil studi menunjukkan bahwa 57 anak balita yang dikelompokkan sebagai kelompok intervensi yang menerima produk liquid 1.5 $\mathrm{kcal} / \mathrm{mL}$ dan 53 balita dikelompokkan sebagai kelompok kontrol menerima produk liquid 1.0 $\mathrm{kcal} / \mathrm{mL}$ masing-masing menunjukkan perubahan berat badan (weight) yang berarti, dimana pada balita yang mengkonsumsi 1.5 $\mathrm{kcal} / \mathrm{mL}$ mengalami kenaikan berat badan sebesar $0.42 \pm 0.40(p=0.43) \mathrm{kg}$ dan pada balita yang mengkonsumsi $1.0 \mathrm{kcal} / \mathrm{mL}$ mengalami kenaikan berat badan sebesar $0.49 \pm 0.49 \mathrm{~kg}$ $(p=0.43)$ selama 28 hari konsumsi.

Atas dasar hasil intervensi PKMK yang telah dilaksanakan ini, maka pada tahun 2019, Pemerintah Kabupaten Banyumas melaksanakan program intervensi pemberian salah satu produk yang digunakan dalam intervensi Deavara et al (2019), yaitu produk liquid $1.5 \mathrm{kcal} / \mathrm{mL}$ (Nutrinidrink Multi FibeR). Akan tetapi dalam pelaksanaan penelitian ini, desain studi tidak menggunakan uji Randomized Control Trial $(R C T)$ dikarenakan keterbatasan data yang dikumpulkan.

Pemberian Makanan Olahan untuk Keperluan Medis Khusus berupa produk liquid $1.5 \mathrm{kcal} / \mathrm{mL}$ ini mengikuti alur Proses Asuhan Gizi Puskesmas 
yang dikeluarkan oleh Kemenkes RI pada tahun 2018. Kriteria inklusi intervensi adalah anak di bawah 5 tahun yang memiliki permasalahan gizi dengan $\mathrm{BB} / \mathrm{TB}<-2 \mathrm{SD}$ dan termasuk ke dalam kelompok balita yang dirujuk untuk mendapatkan intervensi karena memiliki asupan nutrisi yang tidak adekuat dan tidak mampu mengkonsumsi makanan yang ada. Pemberian pangan olahan berupa produk liquid $1.5 \mathrm{kkal} / \mathrm{mL}$ disesuaikan dengan tingkat kebutuhan anak yang diintervensi.

Studi estimasi biaya intervensi PKMK di level Puskesmas sangat jarang dilakukan. Padahal, estimasi biaya intervensi perbaikan gizi di beberapa puskesmas di kabupaten Banyumas ini akan sangat diperlukan guna mendapatkan gambaran awal mengenai sumber daya yang dibutuhkan dalam menjalankan intervensi PKMK terutama di level Puskesmas. Oleh karena itu, guna memaksimalkan upaya perbaikan gizi balita di tingkat Puskesmas, kabupaten Banyumas adalah kabupaten intervensi yang dipilih untuk dilaksanakan studi ini.

Di sisi lain, evidence terkait luaran dari program intervensi juga sangat dibutuhkan guna melihat apakah program intervensi mampu memperbaiki status gizi balita di kabupaten Banyumas atau tidak. Namun, evidence dalam hal luaran ini masih sangat lemah dikarenakan banyaknya variabel pengganggu yang tidak diadjust dalam studi ini.

Studi ini merupakan studi deskriptif yang dilaksanakan untuk mengetahui estimasi biaya yang dibutuhkan untuk melaksanakan program intervensi PKMK pada balita dengan status gizi yang tidak adekuat di Banyumas selama 28 hari dan mengetahui dampak pelaksanaan intervensi terhadap perbaikan status gizi buruk pada balita di Banyumas. Hasil penelitian ini diharapkan dapat dijadikan sebagai referensi dalam hal pelaksanaan upaya-upaya perbaikan gizi balita di daerah terutama melalui intervensi PKMK dengan pelaksanaan pada skala yang lebih besar dan sebagai bahan referensi untuk penelitian selanjutnya dengan menggunakan desain studi yang berbeda.

\section{Metode Penelitian}

Penelitian ini dilakukan dengan pendekatan kualitatif dan kuantitatif. Pendekatan kualitatif dilakukan guna mengangkat isu-isu penting terkait pelaksanaan program intervensi sebagai pendukung data kuantitatif. Sementara itu, pendekatan kuantitatif dilakukan dengan mengumpulkan data primer berupa data terkait estimasi biaya keseluruhan dari pelaksanaan program intervensi dan data terkait luaran (outcome) dari program intervensi.

Keterbatasan dalam studi ini adalah dalam hal data biaya. Biaya yang dikumpulkan merupakan data retrospektif terkait data biaya program intervensi yang dilaksanakan pada tahun 2019. Sedangkan data evaluasi pertambahan Berat Badan (BB) dan Tinggi Badan (TB) balita selama mengikuti program intervensi telah dicatat hari per hari pada saat intervensi mulai dari hari ke-1 sampai hari ke-28 yang direkapitulasi dalam bentuk data laporan format excel. Akan tetapi evaluasi ekonomi dalam studi ini hanya dilakukan secara parsial, terdapat kekurangan studi dimana dari seluruh jenis biaya yang dikeluarkan tidak di-adjust nilai inflasi maupun nilai depresiasinya.

Studi ini merupakan studi deskriptif observational yang menggambarkan estimasi biaya yang dibutuhkan untuk melaksanakan program intervensi PKMK. Jenis biaya yang dihitung mencakup biaya langsung operasional dengan perspektif institusi pelaksana program baik yang dialokasikan oleh Dinas Kesehatan maupun Puskesmas. Biaya yang dikeluarkan antara lain biaya untuk fasilitas dan peralatan, biaya produk, biaya tenaga gizi dan tenaga lainnya yang berkontribusi untuk program, biaya pelatihan dan sosialisasi, serta biaya monitoring evaluasi. Biaya fasilitas mencakup biaya yang 
dikeluarkan untuk alat ukur antropometri, alat ukur BB, alat ukur TB, dan fasilitas lain yang membutuhkan biaya. Sementara itu, biaya peralatan mencakup biaya box penyimpanan. Sedangkan, biaya produk gizi adalah biaya yang dikeluarkan untuk produk gizi $1.5 \mathrm{kcal} / \mathrm{mL}$, biaya tenaga gizi mencakup gaji nutrisionis dan biaya tenaga lain mencakup biaya insentif untuk kader/bidan/staf. Dan, biaya sosialisasi mencakup biaya sosialisasi program serta materi edukasi untuk pelaksanaan program.

Tidak ada biaya tidak langsung yang diklasifikasi dikarenakan produk suplementasi gizi yang digunakan dalam program intervensi diantar oleh tenaga kesehatan ke rumah balita langsung, tidak ada biaya out of pocket yang dikeluarkan oleh pasien maupun oleh orang tua pasien seperti biaya transportasi atau konsumsi. Sementara itu, konsekuensi biaya dari sisi Dinas Kesehatan dan puskesmas saat melakukan pengantaran produk PKMK telah dimasukkan ke dalam klasifikasi biaya sebelumnya, yaitu biaya langsung untuk tenaga kesehatan dan tenaga lainnya.

Sampel dalam studi ini adalah purposive sampling, keseluruhan anak yang diintervensi PKMK di kabupaten Banyumas pada bulan Juli sampai Agustus tahun 2019. Balita yang menjadi sampel adalah balita yang telah di-screening sebelumnya oleh pihak Puskesmas. Pada bulan Juli sampai Agustus tahun 2019, total terdapat sebanyak 40 balita dari 33 puskesmas yang berbeda di kabupaten Banyumas yang diikutkan dalam intervensi. Pemilihan 40 balita yang diintervensi dengan inklusi kriteria merupakan pasien yang memiliki asupan nutrisi yang tidak adekuat dan ketidakmampuan mengkonsumsi makanan yang ada, sehingga menyebabkan pasien membutuhkan PKMK. Pemilihan sampel telah ditentukan pada saat intervensi/sebelum studi dilakukan merujuk kepada tahapan Proses Asuhan Gizi yang dikeluarkan oleh Kemenkes RI pada tahun 2018. Sementara itu, informan yang diwawancara dengan rincian sebagai berikut: 1 informan dari Dinas Kesehatan yaitu penanggung jawab program gizi Dinkes, 33 orang perwakilan Puskesmas yang terlibat dalam program intervensi dan 40 orang tua/caretaker perwakilan orang tua pasien yang mengikuti program intervensi.

Selanjutnya, informasi terkait jenis makanan yang dikonsumsi selama mengikuti intervensi dikumpulkan dari setiap orang tua/caretaker yang anaknya mengikuti intervensi dengan menggunakan instrumen food recall. Food recall dicatat selama beberapa kali selama intervensi. Protokol tersebut telah disetujui oleh Komite Etik Fakultas Kedokteran Katolik Indonesia Atma Jaya (No: 03/12/KEP-FKIKUAJ/2020).

\section{Hasil}

Hasil analisis Kuantitatif dan kualitatif Estimasi Biaya Program Intervensi PKMK berdasarkan tahapan intervensi

Rangkaian kegiatan PKMK dilakukan dari mulai kegiatan pemeriksaan gizi klinis, pengukuran antropometri sampai kepada pencatatan kenaikan Berat Badan (BB) dan Tinggi Badan (TB) anak setelah intervensi PKMK. Program intervensi PKMK berdasarkan fase kegiatan; pre-intervensi, intervensi dan post intervensi dapat dilihat pada grafik di bawah ini. 


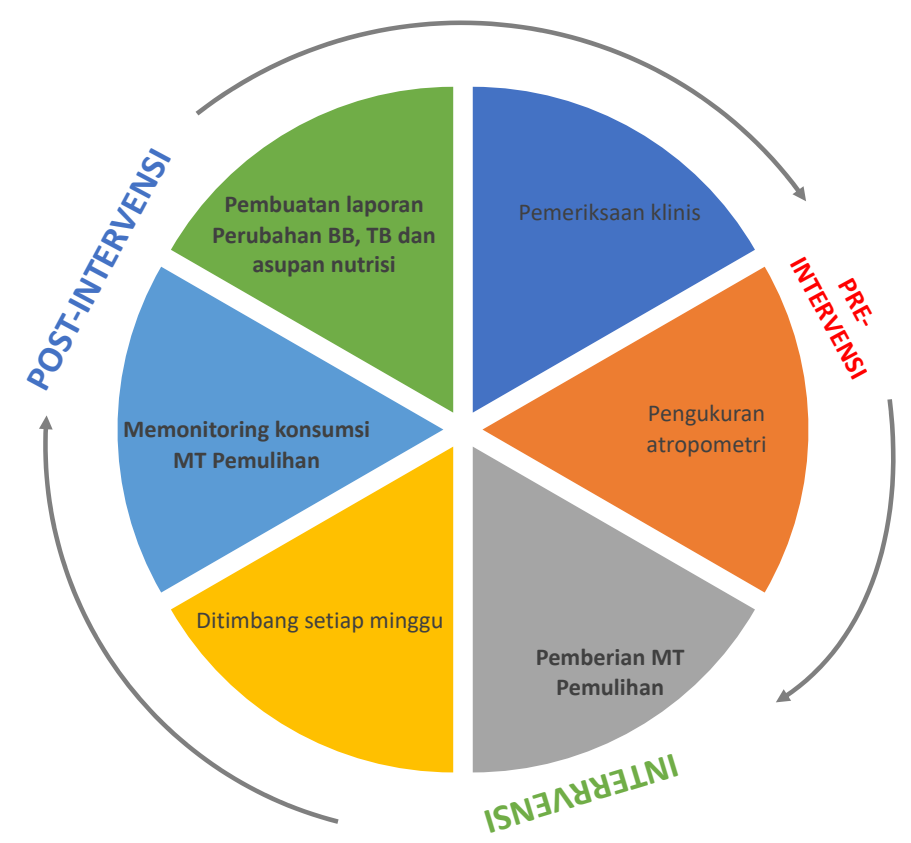

Grafik 1. Rincian kegiatan program intervensi PKMK Pre-intervensi, intervensi dan post intervensi.

Pertama, kegiatan pemeriksaan gizi klinis, kegiatan pengukuran antropometri dan kegiatan pencatatan dan pengelompokan anak balita yang membutuhkan pangan olahan dengan kebutuhan medis khusus merupakan rangkaian kegiatan preintervensi. Kegiatan pre-intervensi tidak bisa berjalan tanpa adanya tenaga gizi puskesmas atau dokter puskesmas guna menegakkan diagnosis anak balita yang membutuhkan PKMK.

"Sudah mencakup dari deteksi dini, edukasi, pemberian nutrisi dan monitoring. Terus untuk deteksi dininya sebelumnya kan saya pernah kunjungan bersama dokter juga ke rumah pasien sebelum program dilaksanakan. Untuk monitoring datang langsung ke rumah pasien kadang dengan bidan desa, tapi lebih sering sendiri." (IN-4)

Kedua, kegiatan intervensi berupa pemberian produk PKMK (Makanan Tambahan Pemulihan) secara keseluruhan dilakukan oleh bidan desa. Bidan desa sebagai penanggung jawab kegiatan intervensi di desa wilayah kerjanya berkewajiban mengantarkan produk suplementasi nutrisi PKMK (MT Pemulihan) ke rumah-rumah balita yang diintervensi.

Ketiga, kegiatan post-intervensi mencakup monitoring evaluasi pemanfaatan produk PKMK oleh balita yang diikutsertakan dalam program agar tidak terjadi penyalahgunaan. Berdasarkan hasil temuan di lapangan didapatkan informasi bahwa bidan desa memiliki peran besar dalam menjalankan program PKMK, karena selain melakukan intervensi berupa pemberian produk PKMK, ia juga melaporkan hasil perubahan Berat Badan (BB) dan Tinggi Badan (TB) balita mulai sejak awal pelaksanaan program sampai minggu ke-IV balita mengkonsumsi produk PKMK.

"Pendataan yang telah dibuat oleh ahli gizi dan bidan desa dilaporkan, kemudian diberikan intervensi, lalu dicek apakah balita tersebut meminumnya atau tidak. Lalu, setelah satu bulan dilaporkan hasilnya. Monitoring dan evaluasi ini masuk ke dalam fase kegiatan post-intervensi. Kegiatan post intervensi pembuatan laporan umumnya 
dilakukan melalui online, yaitu dengan mengirimkan email laporan ke Dinas Kesehatan." (IN-1)

Program intervensi PKMK di kabupaten Banyumas dalam pelaksanaannya masih tidak disertai dengan edukasi pola asuh. Edukasi pola asuh yang tepat pada saat intervensi sebenarnya dapat dimasukkan ke dalam kelompok kegiatan pre-intervensi dan bermanfaat untuk mengontrol dan memaksimalkan pelaksanaan program.

"Kalau untuk meningkatkan gizi balita sampai ke status gizi baik sih belum ya mba kalau di puskesmas Somagede. Dalam jangka waktu satu bulan susah ya mba untuk menaikan dari -4 sampai dengan normal, diatas -3 susah banget. Kalau menurut saya dalamwaktu 1 bulan kayanya engga mungkin. Melihat dari orang tuanya seperti apa, dari faktor lingkungannya, dari pola asuhnya. Jadi menurut saya belum berhasil 100\%. Karena kenaikan BB juga tidak terlalu signifikan juga. Kalau tidak salah ada distribusi untuk Nutrinidrink lagi, saya berikan ke balita lain dengan pola asuh yang berbeda dengan kasus gizi buruk hanya minus berapa, itu lebih efektif. Mungkin pas dulu tahun 2019 itu si balita tersebut gizi buruk banget, dalam jangka waktu 1 bulan susah." (IN-5)

Estimasi biaya program PKMK berdasarkan fase kegiatan pre-intervensi, intervensi dan postintervensi dalam jumlah rupiah dan persentase dapat dilihat pada grafik di bawah ini.

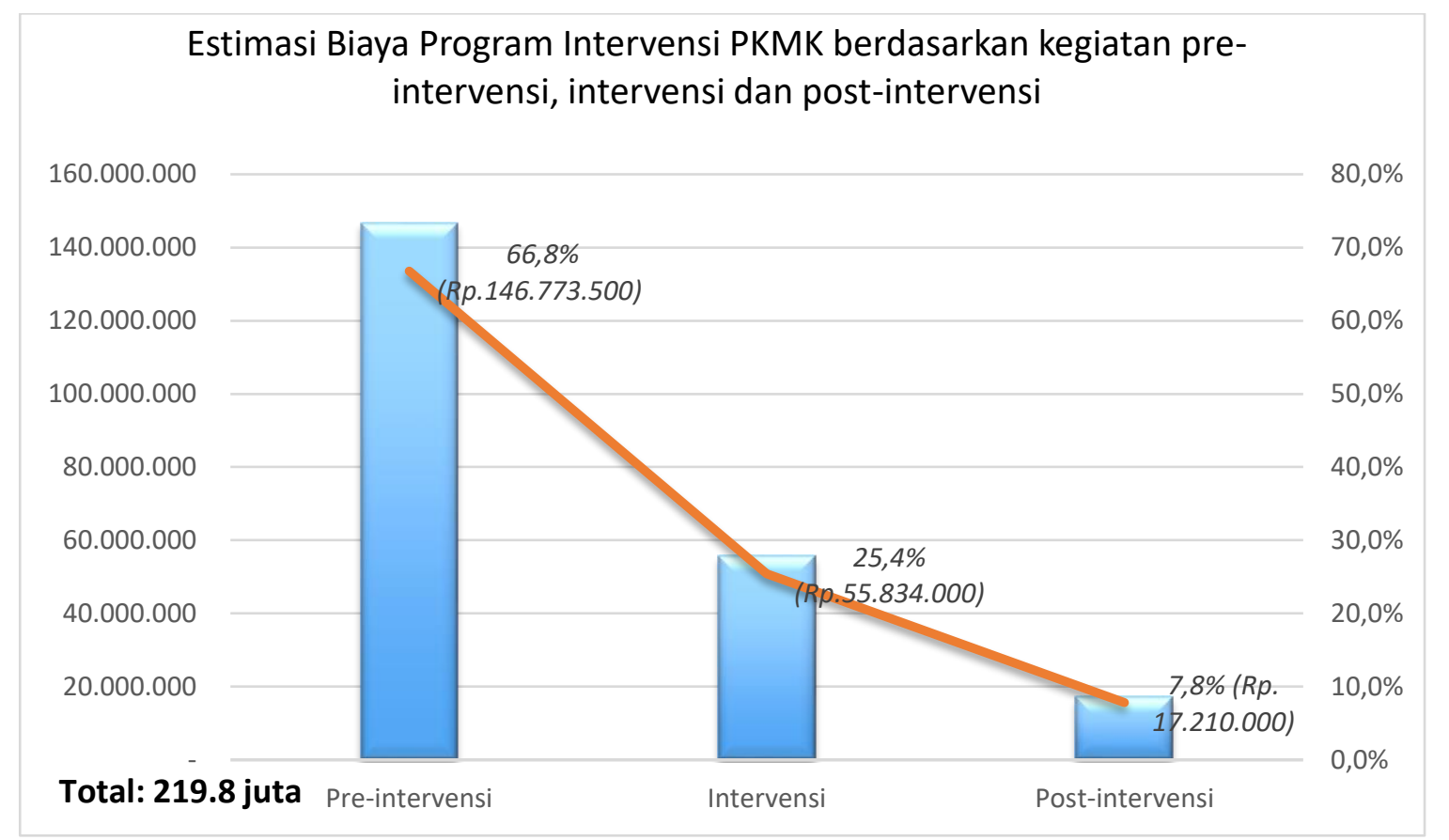

Grafik 2. Estimasi Biaya program intervensi PKMK Pre-intervensi, intervensi dan post intervensi

Dari grafik di atas dapat dilihat bahwa biaya intervensi (25.4\%) pada dasarnya hanya menghabiskan seperempat dari total biaya yang dibutuhkan untuk pelaksanaan PKMK. Sedangkan biaya yang dibutuhkan lainnya adalah biaya pre- intervensi (68.8\%) yang mencakup semua biaya untuk kegiatan sebelum intervensi, dan biaya postintervensi (7.8\%), yaitu mencakup seluruh kegiatan setelah dilaksanakannya intervensi. 
Hasil Analisis Kualitatif Gambaran Hasil analisis data kualitatif didapatkan data Pelaksanaan Program Intervensi Pemberian Pangan Olahan untuk Keperluan Medis Khusus (PKMK) di Kabupaten Banyumas rincian kegiatan pelaksanaan program intervensi PKMK seperti ditunjukkan pada gambar di bawah ini.

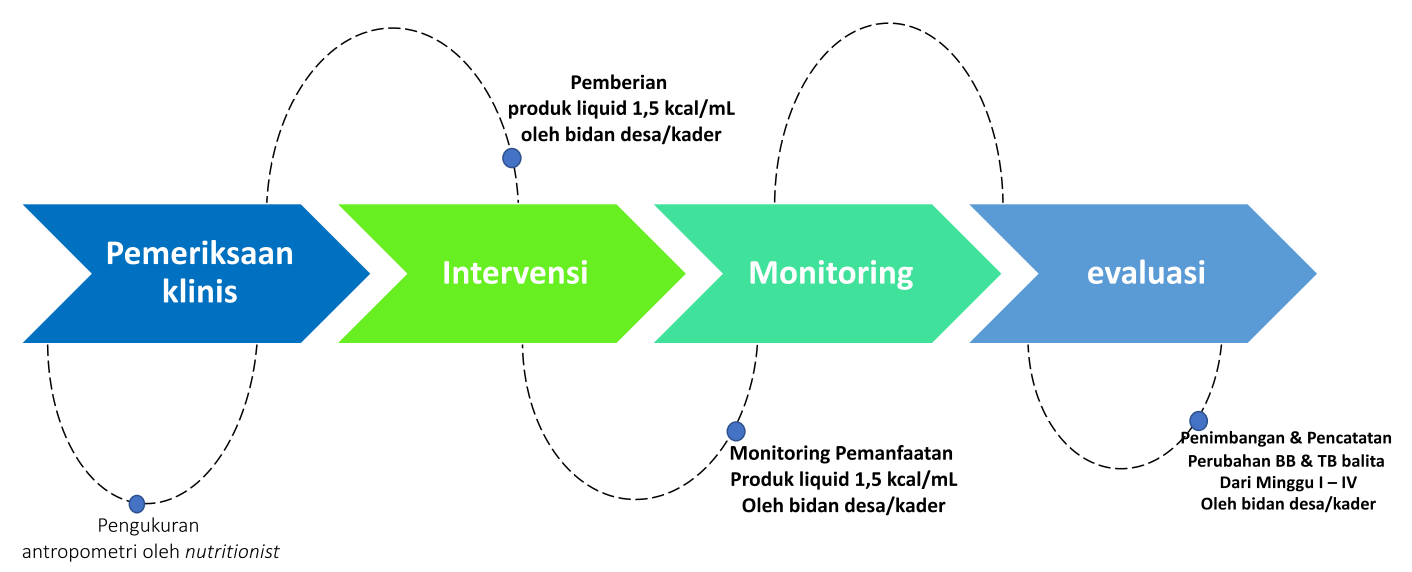

Gambar 1. Alur Proses Asuhan Gizi Intervensi PKMK

Dari gambar di atas dapat dilihat bahwa proses asuhan gizi dalam intervensi PKMK meliputi: (1) kegiatan pemeriksaan klinis untuk pengelompokan balita yang membutuhkan produk PKMK yang dilakukan oleh tenaga gizi puskesmas dan/atau bidan desa dengan melakukan pengukuran antropometri, (2) kegiatan intervensi PKMK untuk balita yang membutuhkan PKMK yang dilakukan oleh bidan desa dan kader dengan memberikan produk PKMK berupa produk liquid $1.5 \mathrm{kcal} / \mathrm{mL}$, (3) kegiatan monitoring yang dilakukan oleh kader dan/atau bidan desa guna memastikan pemanfaatan produk liquid 1.5 $\mathrm{kcal} / \mathrm{mL}$ tepat sasaran, dan (4) kegiatan evaluasi yang dilakukan oleh kader dan bidan desa berupa penimbangan dan pencatatan yang dituangkan dalam laporan perubahan BB dan TB balita setelah intervensi guna diserahkan kepada Dinas Kesehatan Kabupaten Banyumas. Dalam pelaksanaan intervensi PKMK, Puskesmas merupakan pelaksana program, sedangkan Dinas Kesehatan Banyumas memiliki tupoksi memberikan arahan materi dan teknis monitoring harian kepada setiap Puskesmas yang melaksanakan intervensi.

\section{Hasil Analisis Kuantitatif dan Kualitatif Estimasi Biaya Program Intervensi Per Puskesmas}

Beberapa Puskesmas berbeda dalam hal jumlah anak yang diintervensi, rata-rata antara 1-2 balita per Puskesmas. Dalam pelaksanaannya juga terjadi perbedaan dalam penyediaan fasilitas dan perlengkapan gizi dikarenakan sebagian puskesmas sudah memiliki dan menggunakan peralatan dan fasilitas yang sudah ada, sedangkan beberapa Puskesmas lainnya ada yang menganggarkan pembiayaan khusus untuk fasilitas dan peralatan tersebut, hal ini akan berdampak terjadinya perbedaan biaya per Puskesmas dalam pelaksanaan intervensi.

Beberapa puskesmas juga tidak menganggarkan biaya honor untuk tenaga kesehatan yang melaksanakan program.

“... Honor gak ada untuk tupoksi dan lain-lain 
karena merupakan indikator kerja kegiatan rutin... Program ini dijalankan saja malah itu tugas utama saya untuk melakukan pemantauan itu..." [IN-5]
Pada grafik di bawah ini dapat dilihat distribusi estimasi biaya program intervensi PKMK per Puskesmas.

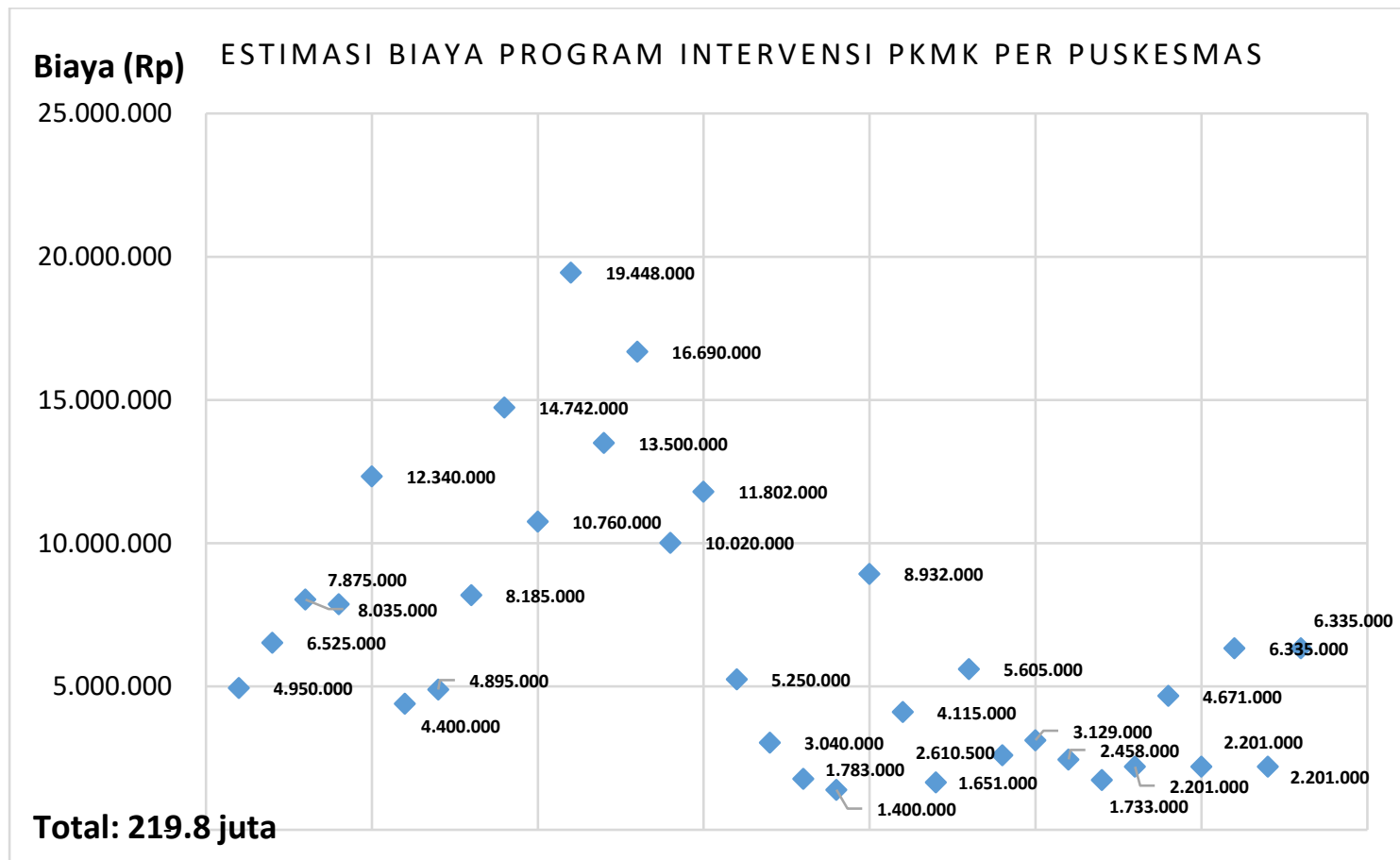

Grafik 3. Sebaran Biaya program Intervensi PKMK Per Puskesmas

Total jumlah puskesmas di kabupaten Banyumas adalah sebanyak 39 puskesmas. Pada bulan Juli-Agustus tahun 2019, intervensi PKMK tidak dilakukan di semua puskesmas di kabupaten Banyumas. Hanya 33 dari 39 Puskesmas yang ikut dalam program ini. Dari ke-33 puskesmas tersebut bisa dilihat bahwa estimasi biaya program intervensi PKMK secara rata-rata per masingmasing puskesmas sebesar Rp. 6.661.136,-- per kali intervensi dengan range biaya yang dikeluarkan Rp. 1.400.000,- - Rp.19.448.000,-.

Dari estimasi biaya ini bisa dilihat bahwa puskesmas dengan alokasi biaya terbesar disebabkan karena jumlah balita yang diikutkan ke program dan tingkat keparahannya lebih tinggi. Hal ini dapat menambah jumlah biaya dari segi jumlah produk yang diberikan untuk balita.
Umumnya, setiap balita yang diintervensi sekurang-kurangnya mendapatkan produk liquid $1.5 \mathrm{kcal} / \mathrm{mL}$ sebanyak 2 botol $200 \mathrm{~mL}$ per hari selama 28 hari, sehingga setiap balita yang diintervensi mendapatkan rata-rata sebanyak 56 botol $200 \mathrm{~mL}$ produk liquid $1.5 \mathrm{kcal} / \mathrm{mL}$ selama intervensi.

\section{Hasil Analisis Kuantitatif dan Kualitatif Biaya Program Intervensi Berdasarkan Klasifikasi Biaya Langsung}

Hasil studi menunjukkan bahwa keseluruhan biaya intervensi PKMK adalah biaya langsung, yaitu belanja kesehatan yang dibelanjakan langsung untuk program seperti biaya untuk produk gizi, biaya untuk tenaga gizi, biaya untuk honor tenaga kesehatan lain dan lain sebagainya. 
Biaya tidak langsung tidak dikeluarkan dalam pelaksanaan program dikarenakan produk liquid $1.5 \mathrm{kcal} / \mathrm{mL}$ diantar oleh bidan ke rumah balita, tidak ada biaya out of pocket yang dikeluarkan oleh pasien maupun oleh orang tua pasien seperti untuk biaya transportasi.
Pada grafik di bawah ini dapat dilihat total estimasi biaya langsung yang dikeluarkan untuk program intervensi PKMK di Kabupaten Banyumas.

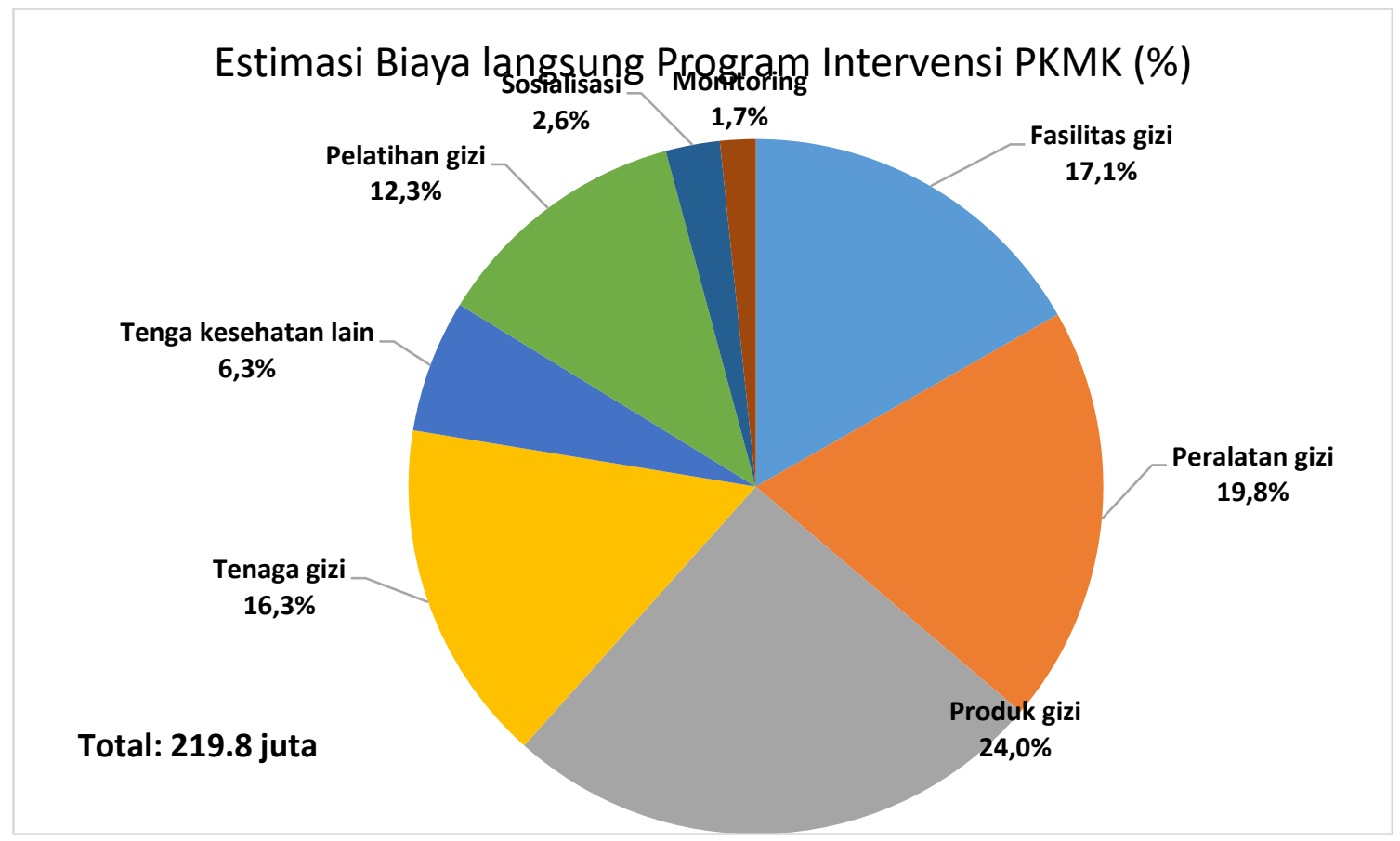

Grafik 4. Estimasi Biaya Langsung program Intervensi PKMK dalam Persentase

Selain untuk pembiayaan produk PKMK (24.0\%), biaya untuk peralatan $(19,8 \%)$ adalah estimasi biaya terbesar kedua setelah biaya untuk produk gizi, disusul biaya untuk fasilitas $(17,1 \%)$, dan biaya-biaya lain seperti biaya untuk tenaga gizi $(16,3 \%)$, pelatihan gizi $(12.3 \%)$, tenaga kesehatan lain $(6,3 \%)$, sosialisasi $(2.6 \%)$, dan monitoring (1.7\%).

Terdapat perbedaan spending pada beberapa puskesmas. Beberapa puskesmas ada yang tidak mendapatkan pelatihan gizi, sementara beberapa puskesmas lainnya, untuk kegiatan monitoring gizinya dilaksanakan tanpa mengeluarkan biaya karena tenaga gizi atau bidannya tidak mendapatkan honor atau biaya transportasi.

Biaya perlengkapan untuk program intervensi
PKMK yang dialokasikan adalah biaya untuk alat penyimpanan produk PKMK berupa lemari dan ruangan khusus untuk penyimpanan. Sedangkan biaya fasilitas dapat berupa alat timbang dan alat ukur tinggi balita. Namun, perlu diperhatikan bahwa estimasi biaya dalam studi ini yang dihitung adalah total biaya riil yang dikeluarkan pada saat pelaksanaan kegiatan tanpa mempertimbangkan dari sisi penyusutan per tahunnya, meskipun alat yang digunakan hanya untuk 1 bulan.

Apabila dilihat dari estimasi biaya dalam jumlah rupiah maka estimasi biaya langsung program PKMK di Kabupaten Banyumas berdasarkan jenis kegiatan dapat dilihat pada grafik di bawah ini. 


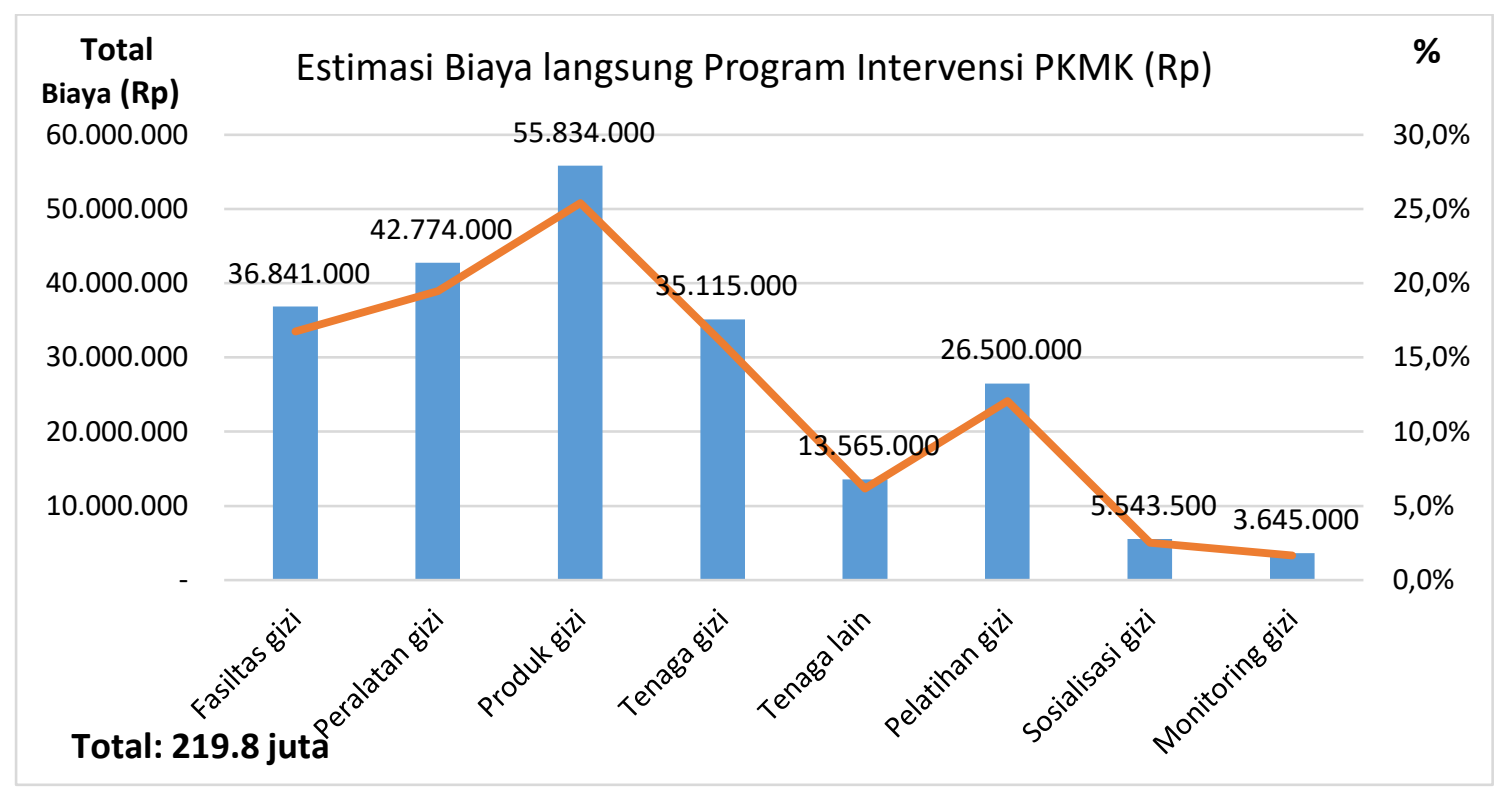

Grafik 5. Estimasi Biaya Langsung program intervensi PKMK dalam Rupiah

Dari grafik di atas dapat dilihat bahwa total biaya intervensi untuk 40 pasien balita yang diintervensi di Kabupaten Banyumas adalah sejumlah Rp. 219.800.000,- dimana biaya yang dialokasikan untuk produk gizi adalah sebesar Rp. 55.834.000, biaya peralatan adalah sebesar Rp.42.774.000, biaya untuk fasilitas sebesar Rp. 36.841.000, biaya tenaga gizi sebesar $\mathrm{Rp}$. 35.315.000, biaya tenaga lain sebesar $\mathrm{Rp}$. 13.565.000, biaya sosialisasi sebesar Rp. 5.543.500, dan biaya monitoring sebesar Rp.3.645.000.

Pada program intervensi PKMK di Banyumas ini, Dinas Kesehatan melakukan pengadaan produk PKMK menggunakan dana APBD. Dana Bantuan Operasional Kesehatan (BOK) berupa dana transfer pusat melalui Kementerian Kesehatan langsung ke rekening puskesmas tidak diperbolehkan digunakan untuk pengadaan produk gizi dikarenakan produk PKMK adalah produk khusus yang membutuhkan pendekatan medis dalam proses pengadaannya. Sementara itu, dana BOK hanya boleh digunakan untuk program perbaikan gizi melalui produk pangan lokal.
“.. Kalau dari puskesmas dulu ada sumber dananya dari BOK, tapi kalau BOK harus pangan lokal jadi kalau dalam bentuk susu belum boleh. Kalau dari APBD mungkin bisa.." (IN-2)

Pengadaan produk PKMK salah satunya dapat dilaksanakan dengan mendorong partisipasi desa secara berkelanjutan untuk penurunan angka stunting di daerahnya. Salah satu informan lain menyatakan bahwa opsi lain apabila hendak melakukan pengadaan produk suplementasi gizi pada skala desa dapat dilakukan dengan memanfaatkan Anggaran Dana Desa (ADD).

"Untuk sumber pembiayaan lain mungkin bisa dari Dana Desa, tapi saya juga kurang paham." (IN-3)

Hasil analisis Kuantitatif Estimasi Biaya Program Intervensi PKMK berdasarkan klasifikasi biaya tetap (fixed cost) dan biaya variabel (variable cost).

Estimasi biaya juga dapat diklasifikasi berdasarkan biaya variabel (variable cost), dan biaya tetap (fixed cost). Biaya variabel yaitu biaya 
yang jumlahnya proporsional dengan jumlah layanan yang diberikan per anak yang mendapat intervensi, semakin banyak anak yang diintervensi, maka biaya ini semakin besar. Sedangkan biaya tetap (fixed cost) adalah biaya yang jumlahnya tetap meskipun terjadi peningkatan jumlah anak yang diintervensi. Estimasi biaya program PKMK di Kabupaten Banyumas berdasarkan biaya variabel dan biaya tetap dapat di lihat di bawah ini.

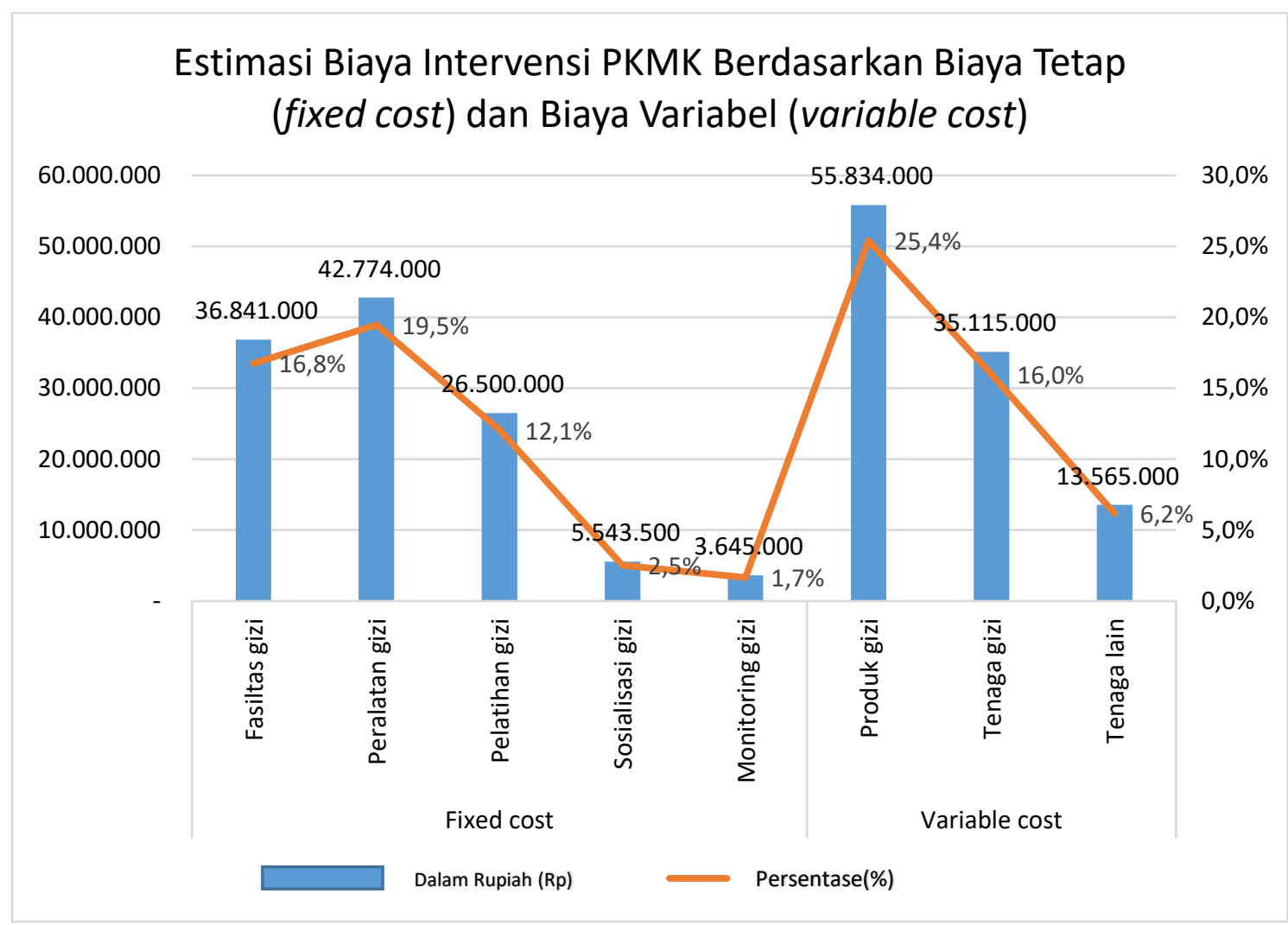

Grafik 6. Estimasi Biaya Variable dan Biaya Tetap Program Intervensi PKMK

Pembagian berdasarkan fixed dan variable cost berguna untuk melihat mana kiranya biaya yang berubah atau tidak berubah apabila ada penambahan jumlah pasien yang diintervensi. Ini juga penting untuk menyimpulkan bahwa beberapa biaya bisa ditiadakan pada pelaksanaan intervensi apabila beberapa item fixed cost (seperti peralatan dan perlengkapan) telah lebih dulu ada di puskesmas.

\section{Hasil analisis Kuantitatif Luaran Dampak Pelaksanaan Program Intervensi PKMK}

Hasil intervensi PKMK berupa perubahan Berat Badan (BB) dalam angka absolut dapat dilihat telah terjadi perubahan pertambahan BB anak balita sebelum dan sesudah intervensi seperti ditunjukkan pada grafik di bawah ini. 


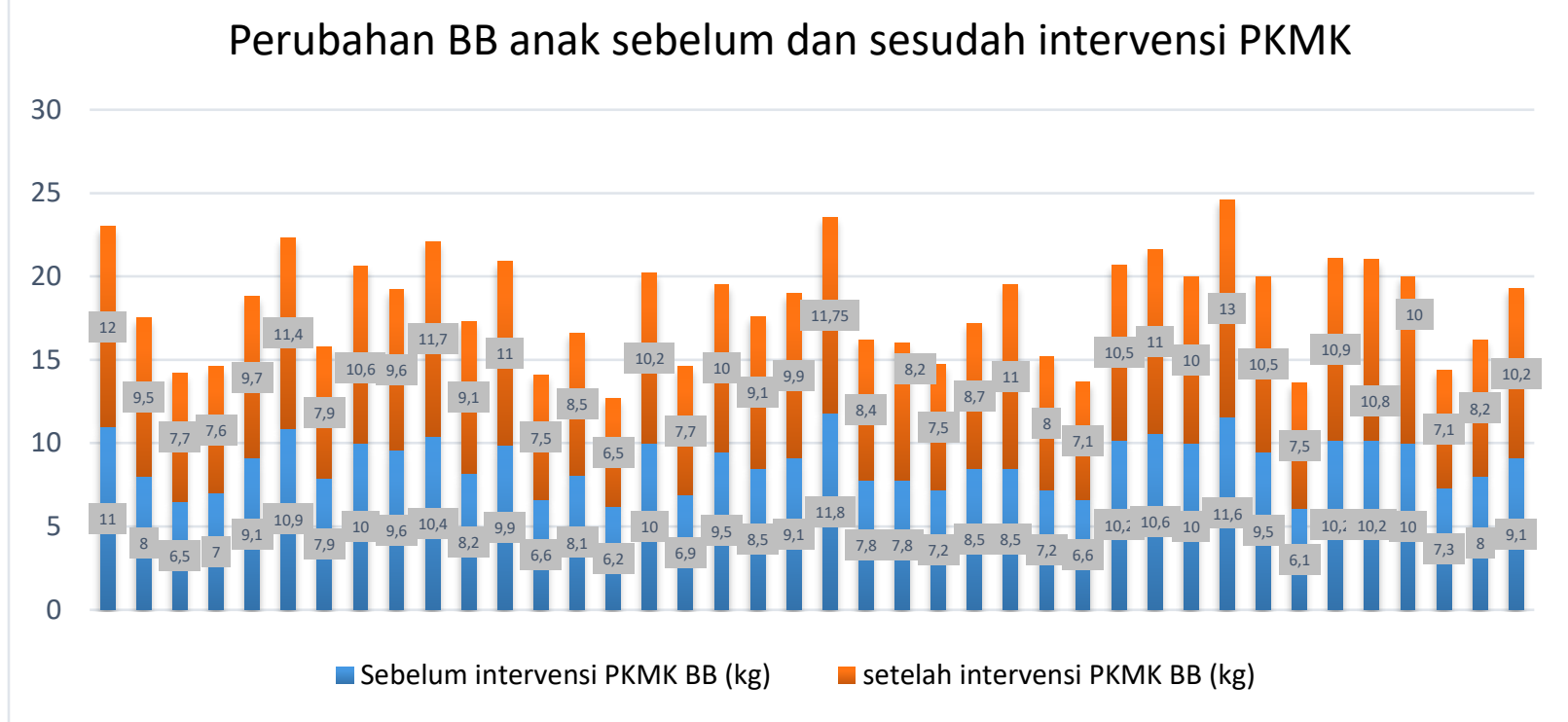

Grafik 1. Perubahan BB balita yang mendapat intervensi PKMK sebelum dan sesudah intervensi

Dari grafik di atas dapat dilihat bahwa perubahan BB anak yang mengikuti intervensi PKMK berada pada angka rata-rata 0.64 kilogram, yaitu di antara range -0.2 sampai dengan 2.5 kilogram. Terdapat 2 (dua) anak balita yang mengalami penurunan BB -0.2 (dari $7.3 \mathrm{~kg}$ menjadi $7.1 \mathrm{~kg}$ ) dan -0.05 (dari $11.8 \mathrm{~kg}$ menjadi 11.75).

Perubahan Tinggi Badan atau Panjang Badan (dalam centimeter) anak sebelum dan sesudah intervensi PKMK dapat dilihat pada grafik di bawah ini.

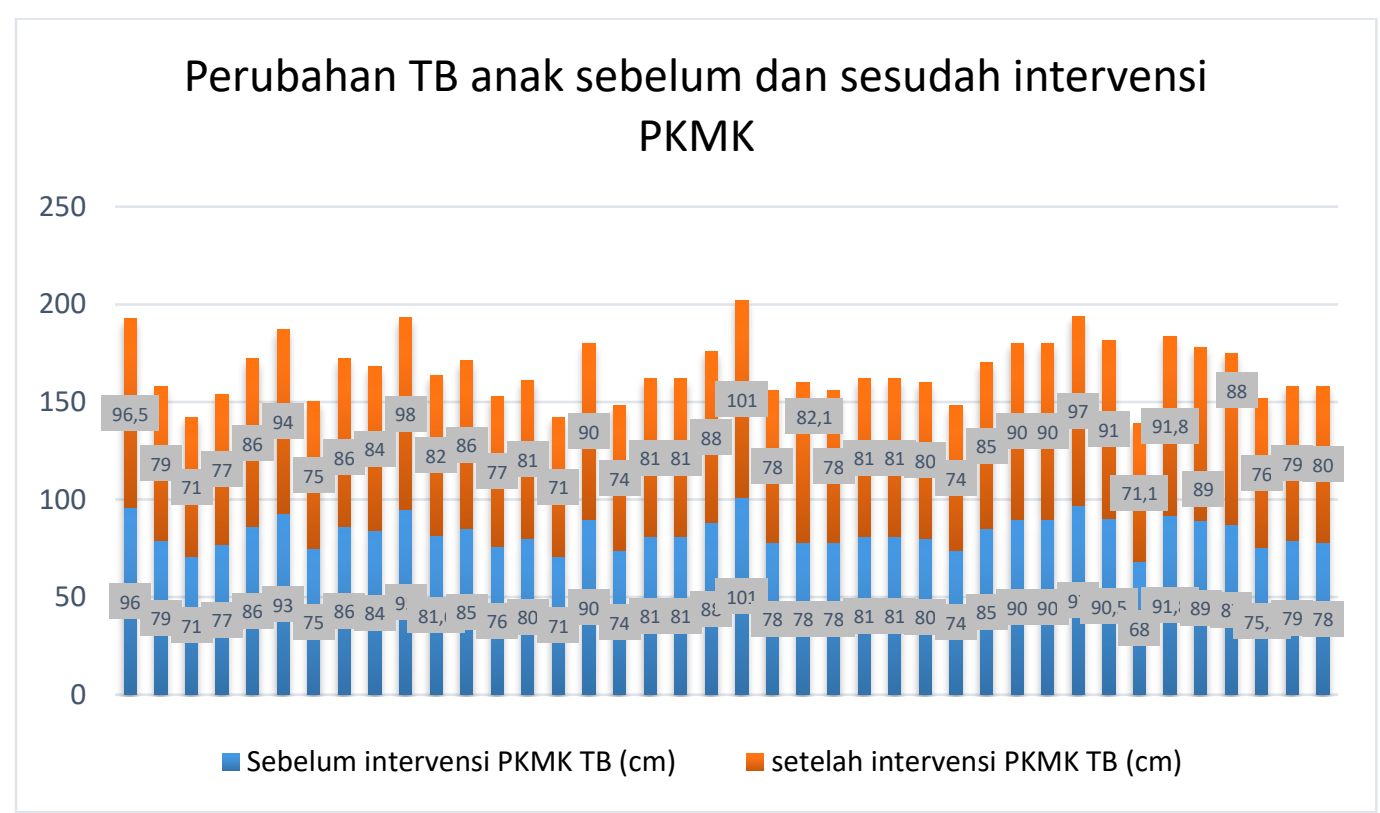

Grafik 2. Perubahan TB balita yang mendapat intervensi PKMK sebelum dan sesudah intervensi 
Grafik di atas menunjukkan bahwa perubahan tinggi anak (per individu) usia 13-59 bulan yang mendapatkan intervensi PKMK sangat beragam, perubahan berada pada angka rata-rata 0.47 centimeter, yaitu pada range 0 sampai dengan 4.1 $\mathrm{cm}$.

Di sisi lain, berdasarkan klasifikasi $\mathrm{BB} / \mathrm{TB}$ "sangat kurus" yaitu balita dengan angka Z-Score $<-3,0 \mathrm{SD}$, status "gizi kurus" yaitu balita dengan angka Z-score $-3,0 \mathrm{SD}$ s/d $<-2,0 \mathrm{SD}$, dan "gizi normal" yaitu balita dengan angka Z-Score-2,0 SD s/d 2,0 SD, maka data perubahan BB/TB anak sebelum dan sesudah pelaksanaan intervensi PKMK dapat dilihat pada grafik di bawah ini.

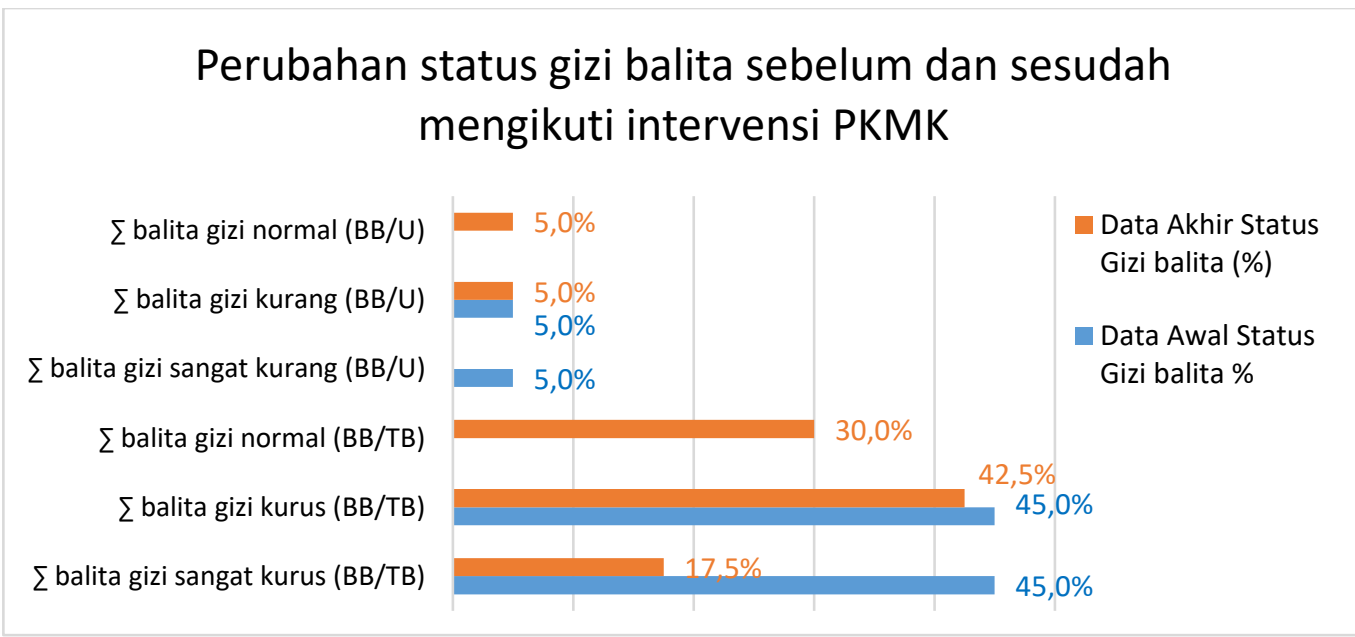

\section{Grafik 3. Perubahan Status Gizi balita sebelum dan sesudah mengikuti intervensi PKMK}

Balita yang memiliki status gizi "sangat kurus" berkurang dari $45 \%$ menjadi $17.5 \%$ - artinya terjadi penurunan sampai $27,5 \%$, begitu pula dengan perubahan jumlah balita dengan status "gizi kurus" (BB/TB) berkurang dari 45.0\% menjadi $42.5 \%$ - artinya terjadi penurunan sampai $2.5 \%$. Dari data akhir status gizi balita juga terlihat terdapat $30.0 \%$ anak balita yang kemudian status gizinya menjadi normal (BB/TB).
Data pola makan anak di rumah dibutuhkan untuk memberi gambaran apa saja makanan selain susu yang dikonsumsi anak di rumah. Data pola makan ini dapat menjadi justifikasi peningkatan BB, TB dan status gizi anak selama mengikuti program intervensi PKMK terjadi dengan asumsi balita tersebut memiliki pola makan seperti ditunjukkan pada grafik di bawah ini.

Tabel 1 Pola Makan Balita Selama Mengikuti program intervensi PKMK

\begin{tabular}{|c|c|c|c|c|c|}
\hline $\begin{array}{l}\text { Kelompok } \\
\text { umur }\end{array}$ & $\begin{array}{c}\text { Jumlah } \\
\text { balita }\end{array}$ & $\begin{array}{c}\text { Menu } \\
\text { Pagi/Siang/Malam }\end{array}$ & $\begin{array}{c}\text { Bahan Makanan } \\
\text { Pagi/Siang/Malam }\end{array}$ & $\begin{array}{l}\text { Berat Bersih } \\
\text { (gram) }\end{array}$ & Nilai Gizi \\
\hline & & & beras, olive oil, & & $100-120$ \\
\hline 6-11 bulan & 1 balita & bubur & kangkung, daging & $15,10,15,15$ & Kkal \\
\hline \multirow{3}{*}{$12-36$ bulan } & \multirow{3}{*}{26 balita } & bubur kacang ijo dan & kacang hijau, gula, & & $150-200$ \\
\hline & & telur & santan, telur & $25,15,5,50$ & Kkal \\
\hline & & $\begin{array}{l}\text { nasi, telur ayam, } \\
\text { savur }\end{array}$ & ur, bayam & 0 & $\begin{array}{c}200-250 \\
\text { Kkal }\end{array}$ \\
\hline
\end{tabular}




\begin{tabular}{|c|c|c|c|c|c|}
\hline $\begin{array}{l}\text { Kelompok } \\
\text { umur }\end{array}$ & $\begin{array}{c}\text { Jumlah } \\
\text { balita }\end{array}$ & $\begin{array}{c}\text { Menu } \\
\text { Pagi/Siang/Malam }\end{array}$ & $\begin{array}{c}\text { Bahan Makanan } \\
\text { Pagi/Siang/Malam }\end{array}$ & $\begin{array}{l}\text { Berat Bersih } \\
\quad \text { (gram) }\end{array}$ & Nilai Gizi \\
\hline \multirow{10}{*}{$37-59$ bulan } & \multirow{10}{*}{13 balita } & $\begin{array}{l}\text { nasi, tempe, ikan, } \\
\text { sayur } \\
\text { Roti tawar, susu }\end{array}$ & beras, tempe, wortel & $50,25,25$ & $\begin{array}{c}200-220 \\
\text { Kkal } \\
100-150\end{array}$ \\
\hline & & coklat & terigu, susu, gula & $50,15,15$ & $\begin{array}{c}\text { Kkal } \\
200-230\end{array}$ \\
\hline & & nasi, sayur lodeh & beras, labu siam, wortel & $50,25,25$ & $\begin{array}{c}\text { Kkal } \\
100-150\end{array}$ \\
\hline & & $\begin{array}{l}\text { roti tawar } \\
\text { biskuit balita/bikuit }\end{array}$ & roti & 50 & $\begin{array}{c}\text { Kkal } \\
150-170\end{array}$ \\
\hline & & MPAsi & gandum & 50 & $\begin{array}{c}\text { Kkal } \\
100-150\end{array}$ \\
\hline & & $\begin{array}{l}\text { nasi,tempe,sosis } \\
\text { nasi, sop/sayur }\end{array}$ & $\begin{array}{l}\text { beras, ikan, daging } \\
\text { beras, wortel, kentang, }\end{array}$ & $50,25,15$ & $\begin{array}{c}\text { Kkal } \\
220-250\end{array}$ \\
\hline & & $\begin{array}{l}\text { bening } \\
\text { nasi,sayur tumis, }\end{array}$ & ayam & $50,25,50$ & $\begin{array}{c}\text { Kkal } \\
200-220\end{array}$ \\
\hline & & $\begin{array}{l}\text { ayam, tahu } \\
\text { nasi, sop, ayam }\end{array}$ & $\begin{array}{l}\text { beras, kubis,wortel,ayam } \\
\text { beras, kentang, wortel, }\end{array}$ & $50,25,15$ & $\begin{array}{c}\text { Kkal } \\
150-220\end{array}$ \\
\hline & & goreng & $\begin{array}{l}\text { daging ayam } \\
\text { tepung terigu/gandum, }\end{array}$ & $50,25,15,15$ & $\begin{array}{c}\text { Kkal } \\
170-180\end{array}$ \\
\hline & & biskuit bayi, susu & susu & 50,25 & Kkal \\
\hline
\end{tabular}

Dari tabel di atas didapat informasi bahwa anak balita yang mengikuti program intervensi PKMK memiliki pola makan yang hampir sama di waktu pagi, siang, dan malam. Range energi yang diperoleh dari sumber makanan yang dikonsumsi sejumlah $100 \mathrm{Kkal}$ - $250 \mathrm{Kkal}$ per kali makan. Pola makan yang sama diulang 3 kali dalam sehari (pagi, siang, dan malam), maka didapat range energi yang diperoleh anak per hari sejumlah 300 - 750 Kkal. Salah satu informan menyatakan puskesmas tidak pernah menekankan kepada makanan apa yang diperbolehkan dan tidak boleh dikonsumsi selama mengikuti program PKMK.

"Sudah dipaksa makan, meskipun dikasih susu dari puskesmas, anak kita tetap dikasih makanan-makanan yang menurut kita baik, walaupun dari puskesmas tidak diingatkan untuk makanan anak seperti apa, yang penting makan.." (IN-6)

\section{Pembahasan}

Studi ini memiliki keterbatasan dalam hal proses pengontrolan selama pelaksanaan program. Terdapat banyak faktor yang tidak di-adjust selama proses intervensi, salah satunya seperti pemberian makanan oleh orang tua balita yang beragam. Tabel 1 menunjukkan jumlah rerata berat bersih bahan makanan yang dikonsumsi dalam gram dan jumlah kalori yang didapat dari makanan tersebut per kali makan. Rerata asupan energi dari bahan makanan yang dikonsumsi (dalam gram) didapat kalori sebanyak $100 \mathrm{Kkal}-$ 250 Kkal per kali makan atau sebanyak 300 - 750 Kkal per hari. Food recall dicatat selama beberapa kali selama intervensi. Food recall yang tidak diamati dan tidak dicatat setiap hari sangat rentan bias, karena bisa saja makanan yang dikonsumsi di saat tidak diamati berbeda dengan pada saat pencatatan. 
Secara keseluruhan total biaya yang dikeluarkan untuk keseluruhan program adalah sebesar Rp.219.817.000 untuk 40 anak yang diintervensi. Dengan rincian biaya per kapita per anak untuk pre-intervensi sebesar Rp.3.669.338 per 28 hari, untuk intervensi sebesar Rp.1.395.850 per 28 hari, dan untuk post-intervensi sebesar Rp.430.250 per 28 hari.

Dalam penelitian Surhayati (2006), pengelompokan biaya intervensi suplementasi gizi berbahan pangan lokal dilakukan berdasarkan biaya investasi, biaya pemeliharaan dan biaya operasional. Hasil studi memperlihatkan rata-rata biaya yang diperlukan sebesar Rp.768.887 per balita per bulan pada tahun 2006 atau setara dengan Rp. 1.268.664 per balita per bulan pada tahun 2019 (discount rate 5\%) telah meningkatkan BB balita sebesar $\pm 0,30 \mathrm{~kg}$ pada satu bulan pertama.

Namun, peneliti melihat perbedaan pengelompokan komponen biaya dan rasio protein energi dalam produk PKMK berbeda dengan produk berbahan pangan lokal - artinya intervensi berbahan pangan lokal tidak dapat dijadikan sebagai pembanding ideal dengan intervensi PKMK yang menggunakan produk liquid 1.5 $\mathrm{kcal} / \mathrm{mL}$. Sehingga, peneliti tidak bisa menyimpulkan apakah intervensi PKMK menggunakan produk liquid $1.5 \mathrm{kcal} / \mathrm{mL}$ cukup mahal atau tidak dari segi biaya.

Di sisi lain, ruang lingkup intervensi juga dapat mempengaruhi biaya yang dibutuhkan untuk intervensi. Kebutuhan biaya intervensi berbasis komunitas akan berbeda dengan kebutuhan biaya untuk intervensi non komunitas. Misalnya, biaya pelaksanaan intervensi di level Puskesmas, bila cakupannya lebih besar maka rata-rata biaya per anak akan lebih kecil terutama dalam hal pembiayaan kegiatan pre-intervensi (yang pada dasarnya merupakan kegiatan dengan komponen biaya tetap). Pada level Puskesmas, biaya peralatan dan fasilitas bisa dimaksimalkan penggunaanya untuk jumlah maksimal balita yang diintervensi dan dapat digunakan berulang kali oleh balita lain pada intervensi selanjutnya. Apabila fasilitas dan peralatan gizi telah tersedia sebelumnya di puskesmas, maka rata-rata per balita yang diintervensi hanya perlu dialokasikan pendanaan untuk variable cost-nya saja berupa biaya intervensi (sebesar Rp.1.395.850 per 28 hari intervensi per anak) dan biaya post intervensi (sebesar Rp.430.250 per 28 hari intervensi per anak).

Hasil studi costing oleh Asian Development Bank (Lindsay H.Allen dan Stuart R. Gillespie) memperlihatkan bahwa unit cost dari program intervensi nutrisi berbasis komunitas (community based) dapat berkisar antara US\$ 3 - US\$ 8 per hari per anak atau berkisar US\$ 84 - US\$ 224 per bulan per anak. Perhitungan estimasi biaya dari ADB tidak jauh berbeda dari perhitungan estimasi biaya dalam intervensi PKMK yakni per balita sebesar 100 US\$ untuk produk suplementasi gizi, sedangkan untuk keseluruhan program per balita adalah sebesar US\$ 377 US\$ (1 US\$ = Rp.14.500).

Lindsay H. Allen dan Stuart R. Gillespie menambahkan bahwa proses untuk memilih dan memprioritaskan tindakan untuk memerangi kekurangan gizi idealnya disesuaikan dengan distribusi masalah kekurangan gizi yang ada di daerah tersebut, sifat dan penyebab masalahnya, serta tergantung pada jenis dan sumber daya yang tersedia yang dapat dimobilisasi.

Keterbatasan dalam studi ini adalah dalam hal data yang digunakan merupakan data retrospektif berupa data recall estimasi biaya program intervensi yang sangat rentan bias. Namun hal ini tidak membatasi pemanfaatan hasil studi yang diharapkan dapat digunakan sebagai gambaran awal untuk menginisiasikan intervensi sejenis di kabupaten/kota lain terutama penerapan intervensi pada lingkup cakupan/kriteria subjek yang sama namun dalam lingkup yang lebih luas.

Meskipun fokus dalam studi ini semata-mata untuk mengidentifikasi biaya terkait pelaksanaan 
program intervensi saja dan tidak melakukan analisis efektivitas yang lebih dalam, namun penulis melihat bahwa biaya yang lebih besar dibutuhkan apabila pelaksanaan intervensi PKMK tidak dilakukan, logikanya balita dengan status gizi kurang yang tidak diintervensi sangat rentan terserang penyakit seperti yang dikemukakan oleh Olofin, et al (2013) dalam studinya yang menyatakan bahwa status gizi kurang pada balita berhubungan dengan peningkatan morbiditas dan mortalitas yang disebabkan oleh penyakit infeksi, seperti infeksi saluran nafas dan diare.

Di sisi lain, WHO juga mengklaim bahwa pendapatan perkapita di negara berkembang seperti Indonesia akan menjadi 7\% lebih tinggi jika setiap anak yang mengalami permasalahan gizi tidak adekuat dilakukan intervensi pemberian makanan olahan. Sementara itu, sebuah studi yang dilakukan oleh Grantham-McGregor et al (2007) menunjukkan bahwa penurunan potensi sumber daya manusia akibat permasalahan gizi yang tidak ditangani dapat menyebabkan penurunan pendapatan lebih dari 20\%, sehingga dapat menghambat pembangunan nasional serta ketidakmampuan dalam mencapai bonus demografi.

Merujuk kepada hasil penelitian didapat bahwa luaran (outcome) intervensi PKMK menggunakan produk liquid $1.5 \mathrm{kcal} / \mathrm{mL}$ dalam waktu tertentu dapat membantu menurunkan jumlah balita "sangat kurus" $(\mathrm{BB} / \mathrm{TB}) \mathrm{di}$ Banyumas. Dari hasil studi didapatkan bahwa balita yang memiliki status gizi "sangat kurus" setelah intervensi berkurang dari $45 \%$ menjadi $17.5 \%$ - artinya terjadi penurunan sampai $27,5 \%$.

Namun, dalam hal ini tentunya studi ini perlu diperkuat dengan penelitian lanjutan menggunakan desain studi terkontrol untuk mengontrol faktor pengganggu dari intervensi seperti perbedaan karakter setiap balita yang diintervensi dan latar belakang sosial ekonomi yang berbeda. Faktor pengganggu yang dapat mempengaruhi hasil intervensi antara lain seperti kondisi awal dan penerimaan tubuh balita terhadap produk gizi secara spesifik patut diperhatikan. Kebutuhan tubuh balita akan asupan zat besi, hanya protein hewani saja dan lain sebagainya akan mempengaruhi outcome dari intervensi yang dilakukan.

\section{Limitasi Penelitian}

Terdapat kekurangan dalam hal desain penelitian, penelitian ini bukan merupakan studi terkontrol, karena penelitian lebih memfokuskan kepada perhitungan estimasi biaya yang dibutuhkan untuk intervensi PKMK sebagai referensi untuk kabupaten/kota lain yang hendak melaksanakan program serupa di daerahnya. Terdapat kekurangan studi dalam hal justifikasi hasil intervensi yaitu peningkatan Berat Badan dan Tinggi Badan balita setelah intervensi. Masih ada faktor-faktor yang tidak terkontrol dari intervensi yang bisa menjadi variabel pengganggu.

Selain itu, terdapat keterbatasan data penelitian, yaitu pada data estimasi biaya yang merupakan data recall dimana biaya yang dikeluarkan tidak di-adjust nilai inflasi maupun nilai depresiasinya.

\section{Kesimpulan dan Saran}

Berdasarkan hasil penelitian diketahui bahwa alur kegiatan intervensi PKMK terdiri dari kegiatan pemeriksaan klinis berupa pengukuran antropometri oleh nutrisionis, dilanjutkan dengan kegiatan pemberian produk liquid $1.5 \mathrm{kcal} / \mathrm{mL}$ oleh bidan desa/kader, kemudian dilakukan monitoring pemanfaatan produk PKMK (produk liquid $1.5 \mathrm{kcal} / \mathrm{mL}$ ), dan yang terakhir penimbangan dan pencatatan perubahan $\mathrm{BB}$ dan TB anak selama mengikuti intervensi dari minggu I sampai minggu ke-IV pelaksanaan program intervensi.

Belum ada pembanding yang ideal dari intervensi suplementasi gizi yang ada untuk menentukan apakah intervensi PKMK lebih efektif atau tidak dikarenakan baik dari sisi biaya 
dan komposisi rasio energi protein nya berbeda.

Dari hasil penelitian ini, penulis menyarankan perlu adanya penelitian lanjutan dengan desain studi terkontrol khususnya dalam hal mengontrol faktor pengganggu yang dapat mempengaruhi luaran (outcome) dari intervensi.

\section{Ucapan Terima Kasih}

Ucapan terima kasih yang tulus saya sampaikan kepada Danone Specialized Nutrition Indonesia yang telah memberikan dukungan terselenggaranya penelitian ini, dan kepada pihak Human Initiative serta semua rekan yang telah membantu penelitian ini.

\section{Daftar Pustaka}

Devaera Y., et al. 2018. Comparing Compliance and Efficacy of Isocaloric Oral Nutritional Supplementation Using $1.5 \mathrm{kcal} / \mathrm{mL}$ or 1 $\mathrm{kcal} / \mathrm{mL}$ Sip Feeds in Mildly to Moderately Malnourished Indonesian Children: A Randomized Controlled Trial. Podiatry Gastroenterol Hepatol Nutrition 2018 October 21(4):315-320

Grantham-McGregor S, Cheung YB, Cueto S, dkk. 2007. Developmental potential in the first 5 years for children in developing countries. The Lancet, 369: 60-70.

Kemenkes RI. 2020. Renstra Kementerian Kesehatan Tahun 2020-2024. Jakarta; 2020.

Kemenkes RI. 2019. Peraturan Menteri Kesehatan RI Nomor 4 Tahun 2019 Standar Teknis Pemenuhan Mutu Pelayanan Standar Pelayanan Minimal Bidang Kesehatan.

Kementerian Kesehatan. 2018. Hasil Pemantauan Status Gizi Tahun 2017. Jakarta; 2018.

Kementerian Kesehatan. 2016. Peraturan Menteri Kesehatan Nomor 51 Tahun 2016 tentang standar produk suplementasi Gizi. Jakarta; 2016.

Kemenkes RI. 2014. Peraturan Menteri Kesehatan RI Nomor 23 Tahun 2014 tentang Upaya Perbaikan Gizi.
Kemenkes RI. 2013. Peraturan Presiden Nomor 42 tahun 2013 tentang Gerakan Nasional Percepatan Perbaikan Gizi. Jakarta; 2013.

Kemenkes RI. Panduan Penyelenggaraan PMT Pemulihan Bagi Balita Gizi Kurang (Bantuan Operasional Kesehatan. Jakarta; 2011.

Kemenkes RI. 2004. Petunjuk Teknis Standar Pelayanan Minimal (SPM) Penyelenggaraan Perbaikan Gizi Masyarakat. Available from: https://docplayer.info/30971605-Petunjukteknis-standar-pelayanan-minimal-spmpenyelenggaraan-perbaikan-gizimasyarakat.html. Diunduh pada hari Kamis, 21 Januari 2021 pukul 15.50 WIB.

Kemenkes RI. 2018. Laporan Riskesdas Banten 2018. Available from: https://drive.google.com/drive/folders/1XYH FQuKucZIwmCADX5ff1aDhfJgqzI-1.

Diunduh hari Senin, 18 Januari 2021 pukul 15.10 WIB.

Kementerian Kesehatan. 2019. Laporan Nasional Riset Kesehatan Daerah (Riskesdas). 2018. Available from: http://labdata.litbang.kemkes.go.id/images/d ownload/laporan/RKD/2018/Laporan Nasio nal_RKD2018_FINAL.pdf. diunduh 01 Desember 2020 pukul 15.00 WIB.

Kemenkes RI. 2017. Ingin Sehat. Mulailah Perhatikan Mikronutrient Tubuh. Available from:

https://www.kemkes.go.id/article/print/1711 0100004/ingin-sehat-mulailah-perhatikanmikronutrien-tubuh.html. Diunduh pada hari Kamis, 4 Februari 2021 pukul 14.58. WIB.

Kementerian Perencanaan Pembangunan Nasional. 2019. Rencana Pembangunan Jangka Menengah Nasional 2020-2024. Jakarta: Bappenas

Olofin I, McDonald CM, Ezzati M, dkk. 2013. Associations of suboptimal growth with allcause and cause-specific mortality in children under five years: a pooled analysis of ten prospective studies. Plos One, 8(5). 
Peraturan Presiden Republik Indonesia Nomor 18 tahun 2020 tentang Rencana Pembangunan Jangka Menengah Nasional 2020-2024. Available from: https://drive.bappenas.go.id/owncloud/index. php/s/4q7Cb7FBxavq31K\#pdfviewer.

Diunduh pada hari Jumat, 22 Januari 2021 pukul 15.53 WIB.

Suharyati, 2006. Cost Effectiveness Upaya Penanggulangan Gizi Metode Positif Deviance dan PMT. Available from: https://media.neliti.com/media/publications/ 39570-ID-cost-effectiveness-upayapenanggulangan-gizi-metode-positifdeviance-dan-pemberi.pdf. diunduh 06 Maret 2020 pukul 15.00 WIB.

Allen LH and Gillespie SR. 2001. What Works? A Review of the Efficacy and Effectiveness of Nutrition Interventions. ACC/SCN: Geneva in collaboration with the Asian Development Bank, Manila.

Unicef. 2020. Nutrition: Tackling the "double burden" of malnutrition in IndonesIa. Available from: https://www.unicef.org/indonesia/nutrition. Diunduh pada hari Rabu, 20 Januari 2021 pukul 12.30 WIB.

World Health Organization. 2017. WHO Global Nutrition Target: Stunting Policy Brief. Available from: https://www.google.com/url?sa=t\&rct=j\&q= $\underline{\text { \&esrc }=\text { s } \& \text { source }=\text { web } \& c d=\& c a d=r j a \& u a c t=}$ $\underline{8 \& v e d=2 a h U K E w i 4 h 7 \_p 3 s b u A h W z I L c A H e}$ uhDCYQFjAAegQIAhAC\&url=https $\% 3 \mathrm{~A} \%$ 2F\%2Fwww.who.int\%2Fnutrition\%2Ftopics $\% 2$ Fglobaltargets stunting policybrief.pdf\& usg=AOvVaw2jz8sRL5WUy71e8JPLttcI.

Diakses pada hari Sabtu, 19 Januari 2021 pukul 14.14 WIB.

World Health Organization. 2020. Global Health Observatory (GHO) data-Child Malnuritrion 2020 [September 5, 2020]. Available from: https://www.who.int/gho/child- malnutrition/en/. Diunduh hari Rabu, 16 Januari 2021 pukul 21.00 WIB.

World Health Organization. 2013. Evaluation Practice Handbook. Geneva (1991).

Available from:

https://apps.who.int/iris/bitstream/handle/10 665/96311/9789241548687_eng.pdf;jsession $\mathrm{id}=5877 \mathrm{E} 03 \mathrm{DFF} 6 \mathrm{C} 99 \mathrm{~A} 2144 \mathrm{~F} 70 \mathrm{FC} 91 \mathrm{D} 49 \mathrm{E}$ 98? sequence $=1$. Diunduh hari Senin, 8

Februari 2021 pukul 19.05 WIB.

World Health Organization. 2013. Childhood Stunting: Context, Causes and Consequences. Available from: https://www.who.int/nutrition/events/2013 ChildhoodStunting colloquium 140ct Con ceptualFramework_colour.pdf. Diunduh hari Rabu, 21 April 2021 pukul 12.24 WIB.

Wong, Brad, et al. Cost-benefit analysis of an early childhood nutrition intervention to prevent stunting in Haiti (2017). Available form: https://cdn2.sph.harvard.edu/wpcontent/uploads/sites/94/2017/09/WongOrazem-Nutrition-2017.10.25.pdf. Diunduh hari Minggu, 14 Februari 2021 pukul 14.31 WIB. 